\title{
Trends in teenage pregnancy in Brazil in the last 20 years (2000-2019)
}

\author{
Denise Leite Maia Monteiro ${ }^{*}$ (1D), Ida Peréa Monteiro² (1D, \\ Márcia Sacramento Cunha Machado 3 (D), Zenilda Vieira Bruno 4 (1), \\ Filomena Aste da Silveira ${ }^{5}$ (1), Marta Francis Benevides Rehme ${ }^{6}$ (1), \\ Albertina Duarte Takiuti ${ }^{1}$, Nádia Cristina Pinheiro Rodrigues ${ }^{8}$
}

\section{SUMMARY}

OBJECTIVE: The aim of this study was to evaluate the frequency of teenage pregnancy in all Brazilian regions and states in the period of 2000-2019 among two age groups, namely, 10-14 and 15-19 years old, and correlate it with the human development index.

METHODS: A cross-sectional study was performed by using the data from the Live Birth Info System from the National Health System's database.

RESULTS: The percentage of live births from teenage mothers (age 10-19 years) in Brazil decreased by 37.2\% (i.e., 23.4 in 2000 to $14.7 \%$ in 2019) in all regions. Amazonas and Maranhão were the only states to show increased fertility rates for teens in the age group of 10-14 years. The fertility index decreased from $80.9-48 \%$ in all states among mothers aged 15-19 years. Only the Southeast and South regions showed levels below the Brazilian average (i.e., 38.2 and 39\%, respectively). The proportion of live birth showed an inversely proportional trend to the human development index score.

CONCLUSIONS: Brazil shows a decline in the percentage of live birth among adolescent mothers and the fertility rate. Live birth is inversely proportional to the human development index score. However, the teenage pregnancy numbers are still high, with great regional inequality in the country.

KEYWORDS: Pregnancy in adolescence. Prevalence. Epidemiology. Social conditions. Human development.

\footnotetext{
'Universidade do Estado do Rio de Janeiro, Centro Universitário Serra dos Órgãos - Teresópolis (RJ), Brazil.

${ }^{2}$ Centro Universitário São Lucas, Secretaria Municipal de Saúde - Porto Velho (RO), Brazil.

${ }^{3}$ Universidade Federal da Bahia, Bahia School of Medicine, Bahiana School of Medicine and Public Health - Salvador (BA), Brazil.

${ }^{4}$ Universidade Federal do Ceará, School of Medicine - Fortaleza (CE), Brazil.

${ }^{5}$ Universidade Federal do Rio de Janeiro, Centro Universitário de Valença - Valença (RJ), Brazil.

${ }^{6}$ Pontifícia Universidade Católica do Paraná, School of Medicine - Curitiba (PR), Brazil.

־Universidade de São Paulo, Faculty of Medicine - São Paulo (SP), Brazil.

${ }^{8}$ Fundação Oswaldo Cruz, Escola Nacional de Saúde Pública Sérgio Arouca, Instituto de Medicina Social da Universidade do Estado do Rio de Janeiro - Rio de Janeiro (RJ), Brazil.

*Corresponding author: denimonteiro2@yahoo.com.br

Conflicts of interest: the authors declare there is no conflicts of interest. Funding: none.

Received on March 06, 2021. Accepted on March 06, 2021.
} 


\section{INTRODUCTION}

Adolescent pregnancy is a major public health problem globally. In developing countries, 21 million adolescents become pregnant between the ages of 15-19 every year, and approximately 12 million give birth. Furthermore, 777,000 births occur to girls under the age of $15^{1}$. Although the estimated overall adolescent-specific fertility rate has declined over the past 20 years $^{1}$, the actual number of births to adolescent girls has only shown a minor decline ${ }^{2}$. Regional differences in adolescent fertility rates exist, and pregnancy is more likely to occur in marginalized communities, often driven by poverty, poor education, and unemployment ${ }^{1}$.

Early pregnancy has numerous health consequences for adolescents and their newborns. Complications during pregnancy and childbirth represent the leading cause of death among girls aged 15-19 years worldwide due to greater risks of eclampsia, puerperal endometritis, systemic infections, and prematurity. Furthermore, social and economic consequences, such as rejection, violence, and interruption of studies, compromise their future ${ }^{1}$.

An epidemiological study conducted between 2000-2011 showed that Brazil experienced a decline in the percentage of live births (LBs) to adolescent mothers from 2001 onward. This decline tended to be inversely correlated to the human development index (HDI) ${ }^{3}$.

This article aims to evaluate the frequency of adolescent pregnancy in Brazil from 2000-2019 in the five different regions, 27 states, and two age groups (i.e., $10-14$ and 15-19 years) while correlating the data with each region's HDI.

\section{METHODS}

A cross-sectional study was conducted using the data from the Brazilian National Information System on Live Births (SINASC), maintained by the Brazilian Unified Health System's Information Technology Department (DATASUS). The aim was to gather the epidemiological data on births reported throughout Brazil ${ }^{4}$. The following variables were used: births according to the mother's place of residence, age, region, and year of birth ${ }^{4}$.

The study population consisted of women who had LBs from 2000-2019, the last year with the available data at the time of the study, in the five official regions of Brazil. Information on the total number of LBs by region and for those in the age groups of 10-14 and 15-19 years was obtained to calculate the percentage of LBs to adolescent mothers. The age-specific fertility rate (ASFR) per 1,000 adolescents in the same age group, as well as in the same region and state, was calculated using the Brazilian Institute of Geography and Statistics (IBGE) population projection tables 5 .
The association between the frequency of adolescent pregnancy and the HDI of each region was analyzed. This represents a summarized measure of the long-term progress as the HDI assesses income, education, and health. Each region's HDI was obtained by calculating the mean of the HDIs of the states pertaining to that region weighted by their respective populations ${ }^{6}$.

The relative and absolute frequencies of LBs according to the mother's age group and year of birth were calculated. The percentage increase or decrease for the period was calculated as follows:

$$
\frac{\% L B_{2019}-\% L B_{2000}}{\% L B_{2000}} \times 100
$$

Choropleth maps were used to describe the results.

Because SINASC is a public-access database, the project did not require a Research Ethics Committee review. R-Project (version 5.4.0) and ArcGis (version 10.0.4) software were used.

\section{RESULTS}

In 2000 , adolescent pregnancy accounted for $23.4 \%$ of all births, decreasing to $19.3 \%$ by 2010 ; then, it remained stable until 2013. Annual reductions were only observed from 2014 (18.9\%) until 2019 (4.7\%). For the 20-year study period, the frequency of LBs to adolescents decreased by $37.2 \%$.

In absolute numbers, there were $750,537 \mathrm{LBs}$ to adolescent mothers in 2000, of which 28,973 LBs were to mothers aged 10-14 years (ASFR 3.4/1,000 adolescents aged 10-14 years) and 721,564 LBs were to mothers aged 15-19 years (ASFR 80.9\%). In 2019, a reduction was observed, with 419,252 (ASFR 2.5\%) and 399,922 births (ASFR 48.0\%), respectively. Stratifying the data by age, the percentage reduction in the age group of 10-14 (15-19 years) was $26.5 \%$ (40.7\%) (Table 1 ).

The North Region had the highest rate of adolescent pregnancy, followed by the Northeast and Central-West regions. Only the Southeast and South regions had rates below the Brazilian average. Figure 1 shows the ASFR distribution by region both in the age groups of $10-14$ and 15-19 years.

Assessing the 2017 HDI for each Brazilian region, the highest HDI was observed in the Southeast and South regions (0.80), followed by the Central-West (0.79), North (0.73), and Northeast (0.71) regions. The rates of LBs to adolescent mothers in the Southeast and South regions were the lowest, which shows an inversely proportional trend to the HDI (Figure 1).

Regarding the frequency of births in the age group of 10-14 years, the highest rates are also concentrated across states in 
Table 1. Distribution of the annual age-specific fertility rate of 10-14-year-old and 15-19-year-old girls (2000-2019).

\begin{tabular}{l|c|c|c|c|c|c} 
Year & $\begin{array}{c}10-14 \text { years } \\
\text { old }\end{array}$ & $\begin{array}{c}\text { Estimated } \\
\text { population aged } \\
10-14 \text { years }\end{array}$ & ASFR/1.000 & $\begin{array}{c}15-19 \text { years } \\
\text { old }\end{array}$ & $\begin{array}{c}\text { Estimated } \\
\text { population aged } \\
15-19 \text { years }\end{array}$ & ASFR/1.000 \\
\hline 2000 & 28,973 & $8,614,988$ & 3.4 & 721,564 & $8,920,682$ & 80.9 \\
\hline 2001 & 27,931 & $8,556,415$ & 3.3 & 696,955 & $8,931,314$ & 78.0 \\
\hline 2002 & 27,664 & $8,519,877$ & 3.3 & 665,437 & $8,874,671$ & 75.0 \\
\hline 2003 & 27,239 & $8,500,653$ & 3.2 & 645,806 & $8,500,653$ & 76.0 \\
\hline 2004 & 26,276 & $8,487,543$ & 3.1 & 635,014 & $8,673,626$ & 73.2 \\
\hline 2005 & 26,752 & $8,473,701$ & 3.2 & 634,385 & $8,595,641$ & 73.8 \\
\hline 2006 & 27,610 & $8,462,615$ & 3.3 & 605,270 & $8,537,516$ & 70.9 \\
\hline 2007 & 27,963 & $8,455,516$ & 3.3 & 582,409 & $8,501,358$ & 68.5 \\
\hline 2008 & 28,678 & $8,451,680$ & 3.4 & 570,560 & $8,482,441$ & 67.3 \\
\hline 2009 & 27,807 & $8,449,676$ & 3.3 & 546,959 & $8,469,621$ & 64.6 \\
\hline 2010 & 27,049 & $8,444,955$ & 3.2 & 525,581 & $8,456,048$ & 62.2 \\
\hline 2011 & 27,785 & $8,453,733$ & 3.3 & 533,103 & $8,445,364$ & 63.1 \\
\hline 2012 & 28,236 & $8,441,389$ & 3.3 & 531,909 & $8,438,804$ & 63.0 \\
\hline 2013 & 27,989 & $8,407,297$ & 3.3 & 532,002 & $8,435,542$ & 63.1 \\
\hline 2014 & 28,244 & $8,351,178$ & 3.4 & 534,364 & $8,434,160$ & 63.4 \\
\hline 2015 & 26,700 & $8,276,054$ & 3.2 & 520,864 & $8,430,077$ & 61.8 \\
\hline 2016 & 24,135 & $8,165,124$ & 3.0 & 477,246 & $8,439,451$ & 56.6 \\
\hline 2017 & 22,146 & $8,052,464$ & 2.8 & 458,777 & $8,427,714$ & 54.4 \\
\hline 2018 & 21,172 & $7,938,241$ & 2.7 & 434,956 & $8,394,229$ & 51.8 \\
\hline 5019 & 19,330 & $7,823,491$ & 2.5 & 399,922 & $8,338,727$ & 48.0 \\
\hline
\end{tabular}

Source: Brazilian Institute of Geography and Statistics (IBGE)-Research Division ${ }^{5}$. Coordination of Population and Social Indicators. The Sector of Studies and Analyses of Demographic Dynamics. Projection of the population of Brazil, and its federative units by sex and age for the period of $2000-2030$. ASFR: age-specific fertility rate.

the North Region: Roraima (7.3\%), Amazonas (6.1\%), and Acre (5.6\%). In the Northeast, the highest rates were in the states of Maranhão (4\%) and Alagoas (3.9\%). Rates lower than $2 \%$ were only in the Southeast and South regions and in the Federal District (the area of the national capital city, Brasília). Amazonas was the only state in the North Region to show an increase in births $(10 \%)$, while in the Northeast Region, only Maranhão showed an increase of $1.9 \%$. All other states experienced a reduction in births.

Similarly, births to adolescents aged 15-19 years are also more frequent in the North Region (75\%), with a $110.6 \%$ rate in Roraima, followed by Amazonas and Acre, each with 84.6\% and next comes the Northeast Region, with an ASFR of $54.5 \%$, with the highest rates in the states of Maranhão (72\%) and Alagoas (63.1\%). The Central-West Region comes in third $(50.1 \%)$, with the highest rates in the states of Mato Grosso (64.7\%) and Mato Grosso do Sul (61.6\%). No state showed an increase in the ASFR for this age group.
In the study period, the North Region presented a percentage reduction of $11.9 \%$ in the age group of $10-14$ years and $32.9 \%$ in the age group of $15-19$ years in terms of ASFR, while the Northeast Region presented a reduction of 16.4 and $35 \%$, respectively. The Central-West, Southeast, and South regions presented reduction rates from 37.6$51.2 \%$ (Table 2).

\section{DISCUSSION}

This study's results complement the published data ${ }^{3}$ by updating the trends of adolescent pregnancy in the period of 2000 2019. It becomes, therefore, the first study based on the national data available from the SINASC/DATASUS database for the year 2019 .

In the study period, a slow decline was initially observed, followed by a period of stability, and then a more consistent reduction in the last five years. After a large increase in adolescent 


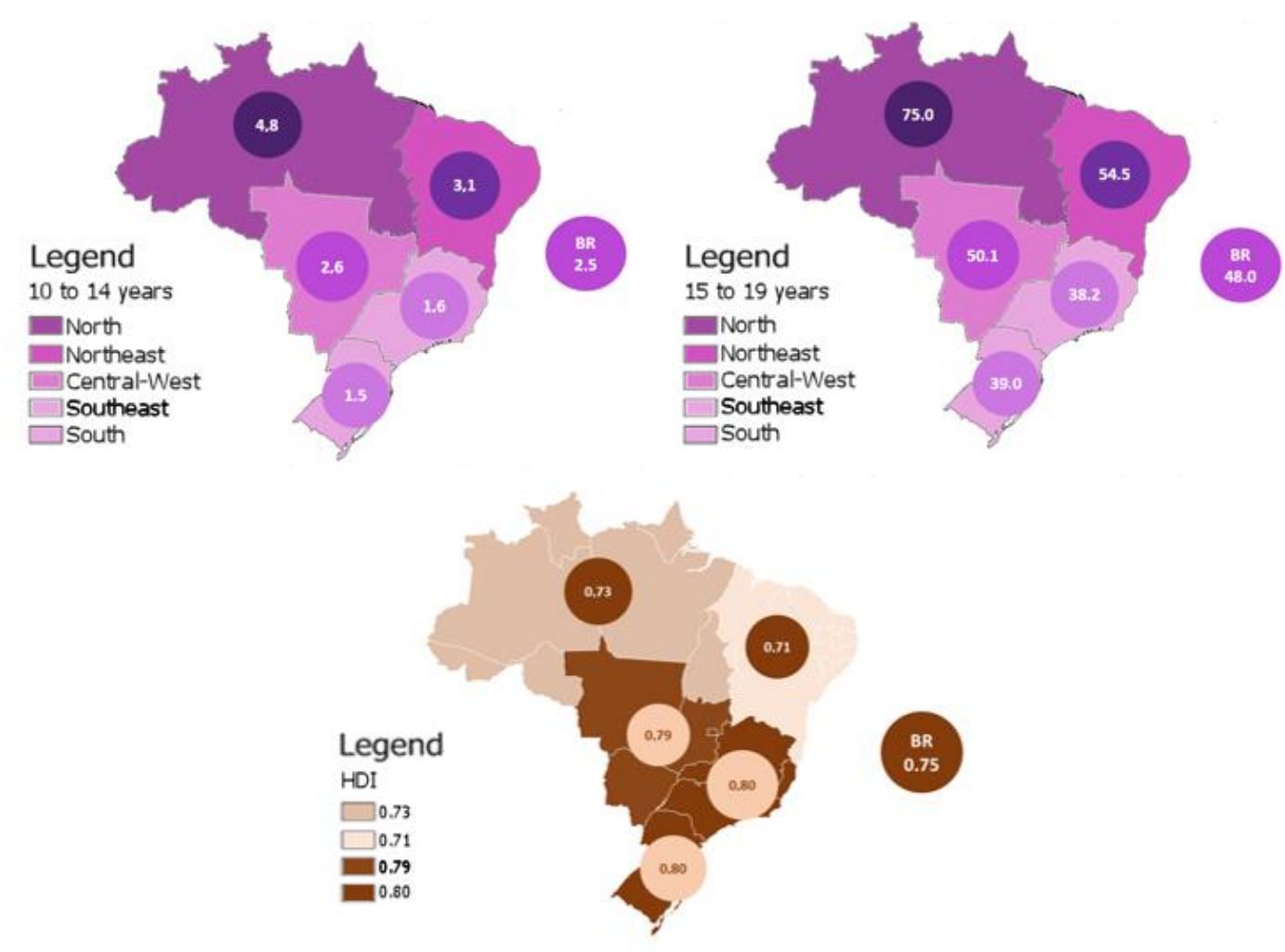

Figure 1. Distribution of age-specific fertility rate per 1,000 adolescents by region (2019) and mean human development index (HDI) by region (2017). Source: DATASUS/SINASC ${ }^{4}$, PNUD Brasil, Ipea e FJP6.

pregnancy rates in the 1990s, Brazil took 15 years to return to the 1994 level (i.e., $19.8 \%$ in both 1994 and 2009).

The pregnancy in adolescents aged 15-19 years, measured by the ASFR, showed a $40.7 \%$ reduction over the study period (from $80.9-48 \%$ ). The international literature only reports the data for this age group, perhaps because pregnancy before the age of 15 years is uncommon in most developed countries.

This study also evaluated the age group of 10-14 years, finding a $26.5 \%$ decrease. These results show progress in the reduction of adolescent pregnancy in relation to the period of 2000-2011, when there was a 5\% increase in the number of LBs to mothers aged 10-14 years, which was even more pronounced in the North (12.5\%) and Northeast (13.4\%) regions. Meanwhile, among 15-19-year-olds, there was a $19.1 \%$ reduction ${ }^{3}$. This study was the first to observe a reduction in adolescent pregnancy in the age group of 10-14 years, which could also be observed in the North (-11.9\%) and Northeast (-16.4\%) regions. The South Region stands out for the highest rate of reduction, from $13 \%$ in $2000-2011$ to $51.2 \%$.
Among mothers aged 15-19 years, the downward trend was observed in the period of 2000-2011 remained. In the North Region, there was a 15 (32.9\%) decrease in 2000-2011 (2000-2019). Similar reductions happened in other regions: Northeast (17.6-35\%), Southeast (22-46.5\%), South (19.948.8\%), and Central-West (27.9-46.7\%) .

The worldwide adolescent fertility rate has decreased by $11.6 \%$ in the past 20 years. However, there are large regional differences, ranging from $7.1 \%$ in East Asia to $129.5 \%$ in Central Africa ${ }^{1}$. In Latin America and the Caribbean, the rate has fallen from $65.6 \%$ (2010-2015) to $60.7 \%$ (2015-2020), representing a $7.5 \%$ decrease. Chile reduced its rate from $53.5-26.5 \%$ between 2010-2017; Uruguay showed a 72\% decline after 20 years, reaching $36 \%$ in 2018 (-50\%). Costa Rica also shows a decline since 2013, going from 29.8 (2013)-21.5\% (2018) ${ }^{7}$.

The United States showed a $59.8 \%$ decline in adolescent ASFR between 2000-2018, but it still exhibits a rate of $18.5 \%$, the highest among developed countries ${ }^{8}$, primarily among Hispanic/Latino, Black, Native Indian, and socioeconomically disadvantaged youth of any race or ethnicity? 
Table 2. Distribution of the age-specific fertility rate per 1,000 adolescents by federative units of Brazil (2000-2019).

\begin{tabular}{|c|c|c|c|c|c|c|c|}
\hline \multicolumn{4}{|c|}{ Adolescents of $10-14$ years old } & \multicolumn{4}{|c|}{ Adolescents of $15-19$ years old } \\
\hline Region & 2000 & 2019 & $\begin{array}{c}\text { ASFR/1000 Evolution \% } \\
\text { 2000-2019 }\end{array}$ & 2000 & 2019 & $\begin{array}{r}\text { ASFR/100 } \\
200\end{array}$ & $\begin{array}{l}\text { volution } \% \\
2019\end{array}$ \\
\hline Brazil & 3.4 & 2.5 & -26.5 & 80.9 & 48.0 & -40.7 & \\
\hline North Region & 5.4 & 4.8 & -11.9 & 111.7 & 75.0 & -32.9 & \\
\hline Roraima & 10.8 & 7.3 & -32.3 & 142.8 & 110.6 & -22.6 & \\
\hline Amazonas & 5.6 & 6.1 & 10.0 & 111.9 & 84.6 & -24.4 & \\
\hline Acre & 7.3 & 5.6 & -23.2 & 134.1 & 84.6 & -36.9 & \\
\hline Pará & 4.9 & 4.6 & -5.9 & 103.4 & 74.0 & 28.4 & \\
\hline Amapá & 6.6 & 4.0 & -39.8 & 129.6 & 68.4 & -47.2 & \\
\hline Tocantins & 6.2 & 3.4 & -44.6 & 120.4 & 59.7 & -50.4 & \\
\hline Rondônia & 4.7 & 2.7 & -43.5 & 118.8 & 55.0 & -53.7 & \\
\hline Northeast Region & 3.7 & 3.1 & -16.4 & 83.8 & 54.5 & -35.0 & \\
\hline Maranhão & 3.9 & 4.0 & 1.9 & 87.1 & 72.0 & -17.4 & \\
\hline Alagoas & 4.8 & 3.9 & -17.7 & 99.8 & 63.1 & -36.8 & \\
\hline Sergipe & 3.9 & 3.2 & -15.9 & 89.2 & 50.0 & -44.0 & \\
\hline Piauí & 3.8 & 3.0 & -22.1 & 93.0 & 57.4 & -38.3 & \\
\hline Bahia & 3.4 & 3.0 & -12.0 & 77.4 & 51.0 & -34.1 & \\
\hline Pernambuco & 3.8 & 2.8 & -26.7 & 90.0 & 53.2 & -40.9 & \\
\hline Paraíba & 3.2 & 2.8 & -12.4 & 72.1 & 53.2 & -26.2 & \\
\hline Rio Grande do Norte & 4.3 & 2.7 & -37.3 & 88.9 & 43.7 & -50.8 & \\
\hline Ceará & 3.5 & 2.7 & -22.2 & 78.6 & 47.5 & -39.6 & \\
\hline Southeast Region & 2.5 & 1.6 & -37.6 & 71.4 & 38.2 & -6.5 & \\
\hline Rio de Janeiro & 3.6 & 2.3 & -35.8 & 79.7 & 45.4 & -43.0 & \\
\hline Espírito Santo & 2.9 & 1.9 & -34.6 & 78.6 & 44.5 & -43.3 & \\
\hline Minas Gerais & 2.0 & 1.6 & -21.0 & 65.0 & 38.1 & -41.4 & \\
\hline São Paulo & 2.4 & 1.3 & -46.1 & 71.1 & 35.1 & -50.6 & \\
\hline South Region & 3.1 & 1.5 & -51.2 & 76.1 & 39.0 & -48.8 & \\
\hline Paraná & 3.3 & 1.8 & -45.9 & 82.3 & 42.2 & -48.8 & \\
\hline Rio Grande do Sul & 3.4 & 1.4 & $-58,7$ & 72.1 & 36.2 & -49.8 & \\
\hline Santa Catarina & 2.4 & 1.3 & -45.9 & 72.2 & 38.0 & -47.4 & \\
\hline Central-West Region & 4.2 & 2.6 & -39.1 & 94.0 & 50.1 & -46.7 & \\
\hline Mato Grosso & 5.2 & 3.6 & -30.7 & 104.8 & 64.7 & -38.3 & \\
\hline Mato Grosso do Sul & 5.5 & 3.5 & -37.1 & 100.0 & 61.6 & -38.4 & \\
\hline Goiás & 3.7 & 2.1 & -43.5 & 93.0 & 45.2 & -51.3 & \\
\hline Federal District & 2.8 & 1.5 & -45.8 & 78.4 & 34.4 & -56.1 & \\
\hline
\end{tabular}

Source: DATASUS/SINASC ${ }^{4}$. ASFR: age-specific fertility rate. 
According to the World Bank, there was also a significant reduction in European countries. In 2000, Germany had a $12.6 \%$ ASFR for the age group of 15-19 years, Portugal had $20.3 \%$, and the United Kingdom had 28.3\%. In 2018, these rates had decreased to $7.8,8.0$, and $12.6 \%$, respectively.

Analyzing the pregnancy in the age group of 15-19 years in five African countries (i.e., Kenya, Tanzania, Uganda, Malawi, and Zambia) shows that social inequalities are evident, with higher rates in adolescents from rural areas, without adequate education, and from poorer families. Knowledge about contraceptive methods and access to schooling were important determinants ${ }^{10}$. In 2017, the fertility rates among 15-19-year-olds in these five countries were $96,132,140,136$, and $141 \%$, respectively ${ }^{11}$.

The World Bank report refers to the "opportunity cost" if additional investment in girls had been made, i.e., the costs associated with adolescent pregnancy and school dropout. Brazil missed out on earning the equivalent of US $\$ 3.5$ billion due to teenage pregnancy, while productivity in India would also increase by US $\$ 7.7$ billion due to the same? .

An estimated 7.5 million girls are married worldwide before the age of $18^{12}$. Brazil ranks fourth in the world for child marriages, with 2.9 million cases. In many places, girls experience pressure to marry and have children early or choose to become pregnant because they have limited educational and employment prospects, contributing to increased rates of adolescent pregnancy and recurrence ${ }^{1}$.

The pandemic caused by severe acute respiratory syndrome coronavirus 2 (SARS-CoV-2) has forced many young people to stay in their homes, which may, therefore, increase domestic and sexual violence as well as adolescent pregnancy ${ }^{7}$.

Adolescents are at risk of repeat pregnancy, as $12-49 \%$ of adolescent mothers become pregnant again within one year after delivery ${ }^{13}$. Silva et al. found among 12,168 adolescents, a pregnancy recurrence prevalence of $29.1 \%{ }^{14}$. An important factor for recurrence is the lack of effective contraception in the postpartum period, with long-acting reversible contraceptives (LARCs) being a good indication in such cases ${ }^{13,15}$.
This study's main limitation is that the available data are on pregnancies that had LBs as an outcome and exclude those with unfavorable outcomes, such as stillbirth or miscarriage. Therefore, the data may be underestimated.

\section{CONCLUSIONS}

Brazil shows a decline in the percentage of LBs among adolescent mothers and the fertility rate. The rate of LBs is inversely proportional to the HDI. However, the teenage pregnancy numbers are still high, with great regional inequality in the country.

Brazil must invest more in specific public policies against unplanned adolescent pregnancy. Reducing school dropouts, providing comprehensive education on sexuality, developing life skills, promoting social changes, and prohibiting early marriages are examples of possible actions ${ }^{12,16}$. Furthermore, the guidance on contraceptive methods, their availability, and encouraging their correct and consistent use, especially of LARCs, are fundamental for responsible sexuality and family planning, which are important for the country to achieve the United Nations' Sustainable Development Goal (SDG) Target 3.1 of reducing maternal mortality to 30 per $100,000^{17}$.

\section{AUTHORS" CONTRIBUTIONS}

DLMM: Conceptualization, Data curation, Formal Analysis, Methodology, Writing - original draft, Writing - review \& editing. ADT: Conceptualization, Writing - original draft. NCPR: Conceptualization, Data curation, Formal Analysis, Methodology. MSCM: Methodology, Data curation, Formal Analysis, Writing - original draft. IPM: Data curation, Formal Analysis, Writing - review \& editing. ZVB: Data curation, Formal Analysis, Writing - original draft. FAS: Data curation, Formal Analysis, Writing - original draft, Writing - review \& editing. MBR: Data curation, Formal Analysis, Writing - original draft, Writing - review \& editing.

\section{REFERENCES}

1. World Health Organization. Adolescent pregnancy. Geneva: World Health Organization; 2020. [cited on Feb. 8, 2021]. Available from: https://www.who.int/news-room/fact-sheets/ detail/adolescent-pregnancy

2. United Nations. Department of Economic and Social Affairs, Population Division (2020). World family planning 2020 highlights: accelerating action to ensure universal access to family planning (ST/ESA/SER.A/450). New York: United Nations; 2020. [cited on Mar. 1, 2021]. Available from: https://www.un.org/development/desa/pd/sites/www. un.org.development.desa.pd/files/files/documents/2020/ Sep/unpd_2020_worldfamilyplanning_highlights.pdf

3. Vaz RF, Monteiro DL, Rodrigues NC. Trends of teenage pregnancy in Brazil, 2000-2011. Rev Assoc Med Bras (1992). 2016;62(4):330-5. https://doi.org/10.1590/18069282.62.04.330

4. Brasil. Ministério da Saúde/DATASUS/SINASC. SINASC-Sistema de Informações de Nascidos Vivos. Brasília: DATASUS; 2008. [cited on Jan. 21, 2021]. Available from: http://www2.datasus. gov.br/DATASUS/index.php?area=060702 5 
5. Brasil. Instituto Brasileiro de Geografia e Estatística. Projeção da população do Brasil e das unidades da Federação. Rio de Janeiro: IBGE; 2013. [cited on Feb. 1, 2021]. Available from: https://www.ibge.gov.br/apps/populacao/projecao/index.html

6. Programa das Nações Unidas para o desenvolvimento. Atlas de desenvolvimento humano no Brasil. Rio de Janeiro: IBGE; 2020. [cited on Feb. 22, 2021]. Available from: http://www. atlasbrasil.org.br/ranking

7. Pan American Health Organization and the United Nations Population Fund. Adolescent pregnancy in Latin America. Technical brief; 2020 [cited on Feb. 1, 2021]. Available from: https://iris.paho.org/handle/10665.2/53133

8. Chaaban J, Cunningham W. Measuring the economic gain of investing in girls: the girl effect dividend. Washington: The World Bank; 2011. [cited on Jan. 16, 2021]. Available from: http:// documents.worldbank.org/curated/pt/730721468326167343/ Measuring-the-economic-gain-of-investing-in-girls-the-girleffect-dividend

9. Williams-Breault BD. Teen pregnancy: United States vs. Europe. Int J Arts Humanit Soc Sci Studies. 2020 [cited on Jan. 21, 2021];5(6):46-54. Available from: https://issuu.com/ijahss. com/docs/1179451174

10. Wado YD, Sully EA, Mumah JN. Pregnancy and early motherhood among adolescents in five East African countries: a multilevel analysis of risk and protective factors. BMC Pregnancy Childbirth. 2019;19(1):59. https://doi.org/10.1186/s12884019-2204-z

11. Fundo das Nações Unidas para a População (UNFPA). Relatório situação da população mundial 2020 - Contra minha vontade: desafiando as práticas que prejudicam mulheres e meninas e impedem a igualdade; 2020. Brasília: Casa da ONU. [cited on
Feb. 5, 2021]. Available from: https://brazil.unfpa.org/pt-br/ topics/swop2020

12. Nações Unidas. ONU News. Unicef: Cerca de $25 \%$ das latinoamericanas casaram-se ou foram viver com seus parceiros antes de completar 18 anos; 2019. [cited on Jan. 31, 2021]. Available from: https://news.un.org/pt/story/2019/10/1690631

13. Han L, Teal SB, Sheeder J, Tocce K. Preventing repeat pregnancy in adolescents: is immediate postpartum insertion of the contraceptive implant cost effective? Am J Obstet Gynecol 2014;211(1):24.e1-7. https://doi.org/10.1016/J.ajog.2014.03.015

14. Silva KS, Rozenberg R, Bonan C, Chuva VCC, Costa SF, Gomes MASM. Gravidez recorrente na adolescência e vulnerabilidade social no Rio de Janeiro (RJ, Brasil): uma análise de dados do Sistema de Nascidos Vivos. Ciênc Saúde Coletiva. 2011;16(5):2485-93. https://doi.org/10.1590/S141381232011000500018

15. Govender D, Naidoo S, Taylor M. Scoping review of risk factors of and interventions for adolescent repeat pregnancies: a public health perspective. Afr J Prim Health Care Fam Med. 2018;10(1):e1-10. https://doi.org/10.4102/phcfm.v10i1.1685

16. World Health Organization. Relatório da ONU diz que 7,3 milhões são mães antes dos 18 anos. ONU News. Geneva: World Health Organization; 2013. [cited on Feb. 5, 2021]. Available from: https://news.un.org/pt/story/2013/10/1455021-relatorioda-onu-diz-que-73-milhoes-sao-mae-antes-dos-18-anos

17. Brasil. Instituto de Pesquisa Econômica Aplicada (IPEA). ODS - Metas nacionais dos objetivos de desenvolvimento sustentável; 2018. [cited on Feb. 5, 2021]. Available from: https://www.ipea.gov.br/portal/images/stories/PDFs/livros/ livros/180801_ods_metas_nac_dos_obj_de_desenv_susten_ propos_de_adequa.pdf. 